\title{
What Factors Affect Financial Transparency Reports? A Study of Regional Government Financial Reports in South Sulawesi Province, Indonesia
}

\author{
Submitted 13/05/20, $1^{\text {st }}$ revision $24 / 06 / 20,2^{\text {nd }}$ revision $18 / 08 / 20$, accepted $30 / 09 / 20$
Jamaluddin Ahmad ${ }^{1}$, Nurjannah Nonci ${ }^{2}$, Achmad Nurmandi ${ }^{3}$, Eko Priyo Purnomo $^{4}$, Agustiyara ${ }^{5}$

\begin{abstract}
:
Purpose: This study aims to analyze and correlate the significant factors that support the financial report system in local government to be more transparent and accountable.

Design/Methodology/Approach: The article analyzes the government apparatuses competence, organization commitment, standard operating procedures, and control system, which are measured by data collected from selected local government and are analyzed through SPPS software. The measurement of financial reports' availability is done through a system-based crosstab correlation technique that displays factors and indicators accordingly. It shows the significance of the correlation between each factor and indicator. The explanation of each factor and indicator is done through quantitative and qualitative research.

Findings: The research found that two main significant factors support transparency and accountability: government competence apparatuses and organizational commitment. On the other hand, two factors are less significant, the standard operating procedures and control system. In terms of indicators, the most significant that supports transparency and accountability, namely government structure, and the weakest indicator is ICT because some do not explicitly use the website-based system's accessibility.

Practical Implications: This paper is a scientific report and can be a policy recommendation to support the local government in achieving transparency and accountability and gaining unqualified opinion.

Originality/Value: There is still a lack of research on developing a local government reporting system by measuring transparency and accountability towards those selected four factors. The value of this paper is to classify affecting factors on the financial reporting system to improve the accountability and transparency of local government.
\end{abstract}

Keywords: Accountability and transparency, report system, local government.

JEL codes: G11.

Paper Type: Research study.

ISSN: 2241-4754, H index 10, Q3.

\footnotetext{
${ }^{1}$ Universitas Muhammadiyah Sindereng Rapang, jahmadlado@umsrappang.ac.id;

${ }^{2}$ Universitas Muhammadiyah Sindereng Rapang

${ }^{3}$ Universitas Muhammadiyah Yogyakarta

${ }^{4}$ Universitas Muhammadiyah Yogyakarta

${ }^{5}$ Universitas Muhammadiyah Yogyakarta
} 


\section{Introduction}

The paper aims to determine the most significant factors supporting the local government's finance report system in achieving transparency, accountability, and a high-level in the financial report system. In Indonesia, the prepared regional financial report system constitutes financial management accountability (Lee-Geiller and Lee, 2019). Accountability is defined as the Government's response to its performance (Pamungkas, Ibtida, and Avrian, 2018). Transparency is the ability to respond to unexpected changes with rapid response and profitability (Ismail, 2020). Furthermore, transparency and accountability are principal of the budget management, and it can be determined into four levels of each performance in local government (Agustin and Arza, 2020; Aminah, Maisyarah, and AlParok, 2020).

According to the Audit Board of the Republic of Indonesia (BPK), BPK states that the best performance of local government in the financial report system is categorized into three levels such as Unqualified opinion (UO), and worse as a Qualified opinion (QO) (Wajar Dengan Pengecualian/WDP) due to the weak management information system, it is referred to which considered as the best opinion on an entity's report (Agustin and Arza, 2020). In other words, it argues Fair Qualification, Unusual Opinion, or Report refusing to give an opinion or not giving an opinion (Disclaimer) (Nuryati, Pratama, and Refina, 2020). An unqualified opinion is an opinion expressed by the auditor after completion of the audit process by the auditing standard and no limitation contained in the audit scope, no significant exception to fairness in the preparation of regional government financial information that is consistently implemented (Pamungkas, Ibtida, and Avrian, 2018).

There are four factors classified in the financial report system: government apparatuses competence, organization commitment, standard operating procedures, and control system. Therefore, the local government should prepare their financial report system that follows the regulation, and the local government should be encouraged to be more transparent and accountable (Tavares and da Cruz, 2017). Adiputra, Utama, and Rossiet (2018) highlighted that government commitment, human resources, ICT, and procedural gain greater pressure in providing local financial information on the official website. As a result, this research tries to look at how the local government in Indonesia achieves the financial report system's highest performance and analyzes the factors that support achieving that performance.

For example, in Malaysia, the Auditor General, who has completed the task of auditing financial statements, will issue a certificate in the form of "not eligible" eligible," "detrimental," or "disclaimer" (Bidin, 2004). In Jordan, the amended audit opinion does not meet the requirements with an explanatory paragraph, which should meet the requirements, disadvantages, and waivers (Alkilani et al., 2020). Therefore, all local governments in Indonesia have sought the highest opinion, i.e., the unqualified opinion. The commitment of the local government to achieve this is very high. The 
greater the promise made by government officials, the better and more responsible for the management of public funds (Hardiningshi et al., 2020).

Moreover, the required regulation of the prepared regional finance report system, resulted very quickly in public information. Local governments may use the internet and media to report and write up their financial reports to increase transparency and financial management accountability. Pamungkas, Ibtida, and Avrian (2018) argue that electronic financial reporting is a cost-efficient and a useful way for local governments to provide financial management information. Thus, local governments may categorize it as an "unqualified opinion" (Agustin and Arza, 2020). Financial reporting and local government budget performance are essential to the credible basis, where the local government needs an internal control system; if they could not meet those factors, the local government may categorize them as less transparent and accountable so that it could transform the financial report system into a low level or unqualified opinion (Dollery et al., 2020)

In dealing with the financial report system, the research focuses on categorizing BPK in correlation with the four factors. Accordingly, Unqualified Opinion (UO), Qualified Opinion (QO), Adverse Opinion (AO), and Disclaimer of Opinion (DoO) which are associated with government apparatus competence; organizational commitment; standard operating procedures; and control system, which refers to the availability of financial report system on the official website of the local government (Adiputra, Utama, and Rossieta, 2018). This study uses a descriptive quantitative method to indicate the availability of information about the local government budget on the financial report system (Lee-Geiller and Lee, 2019).

We can name the agile-adaptive approach, transparency policy, and citizen voluntary cooperation as conceptual recommendations (Moon, 2020). Digital transformation is a strategic imperative for the government (Gong, Yang, and Shi, 2020). To achieve the highest opinion in managing the budget is needed a perfect management information system. Agility governance spreads technology in work processes and improves organizational processes (Dittrich, Pries-Heje, and Hjort-Madsen, 2005). The research tries to explore the quality of transparency and accountability in financial management.

\section{Literature Review}

\subsection{Budget Allocation Performance}

In the context of budget allocation, improved transparency is urgently required (Dittrich, Pries-Heje, and Hjort-Madsen, 2005) to improve the ability to respond to unexpected changes with rapid response and profitability (Hassan Ismail, 2020) and to improve the ability to adapt or respond to external stimuli effectively and efficiently (Paul, Jena, and Sahoo, 2020). The proposed procedure's high efficiency has 
demonstrated a set of budget allocation to continuously adjust the strategic direction as a function of strategic ambition and changing circumstances (Khan, Soundararajan, and Shoham, 2020). Fundamentals of agile technology consist of three main parts: responsiveness, flexibility, and competence (Ezcan, Goulding, and Arif, 2020).

The local government shows a receptive understanding and can anticipate changes and environmental risks (Nurmandi and Purnomo, 2015). The ability to adapt to change can also achieve internal capacities to serve the new opportunities presented (Pereira et al., 2020). The government can appreciate the direct reactions to technology and how it can influence change (Ezcan, Goulding, and Arif, 2020) and the responses of certain stakeholders (Doz, Kosonen, and Virtanen, 2018). When there is a change in an organizational process, it is desired to return to stability (Ezcan, Goulding, and Arif, 2020). Thus, the ability to react is the ability to anticipate changes in the environment, react quickly to opportunities, and recover after the change.

Performance means the flexibility of human resources, the flexibility of information technology, and processes' flexibility. The flexibility of human resources includes the rapid learning of new procedures and the resolution of specific problems (Month, 2020), including the possibility to learn quickly from mistakes (Pfeffermann, 2020), the rapid learning of how to apply the new standard operating procedures and the ability to change positions of responsibility for standardization (Idowu et al., 2020), changing habits, and behavior (Trost, 2020). Information technology flexibility includes developing information technology infrastructure design (Cleveland and Cleveland, 2020; Helms and Nixon, 2010) to manage user numbers, workload changes, and transactions. The development of a modern information technology infrastructure can be easily used (Zykov and Singh, 2020) to fundamentally reform information technology's structure and evolution (Helms and Nixon, 2010). Finally, the flexibility of processes consists of the development of various solutions (Çağlar Kalkan and Aydın, 2020), the availability of mobility (Pfeffermann, 2020), and easy uniformity in change (Hassan Ismail, 2020).

The Change Process is a reengineering process to maintain stability (Trost, 2020). It provides services and support (Ezcan, Goulding, and Arif 2020; Trost, 2020), as well as communication development (Bourjade et al., 2020; Idowu et al., 2020). Finally, Business Strategy Development is developing information technology strategies or information systems (Pfeffermann, 2020), HR strategy development, and training strategy development (Ezcan, Goulding, and Arif, 2020).

In Indonesia, the local government's financial reporting system's quality or performance refers to the regulation in the BPK RI audit results presented in the form of an audit opinion of the local government (Ode Hasiara, 2017). The report is an indicator of the quality of financial responsibilities, as reflected in the local government (LKPD). The performance of the report would get an opinion on four levels, namely: Unqualified Opinion (UO), Qualified Opinion (QO), Adverse Opinion $(\mathrm{AO})$, and Disclaimer of Opinion (DoO). 


\subsection{Transparency and Accountability}

Transparency and accountability are the basic characteristics of government as an institution (Lee-Geiller and Lee, 2019). Transparency has the role of encouraging access to information and facilitating community involvement. The government provides detailed and essential information and maintains public access (Tavare and da Cruz 2017). Adiputra et al. (2018) said that one of the problems affecting communities is the lack of accessibility to government-held information. Due to the correlation between responsibility and ethical issues, corruption, bureaucracy, obligations or inertia bureaucracy (Purnomo et al., 2019), transparency is one of the key aspects of good governance in ensuring access for all, including public expenditure management, information on governance (Medina, 2012).

A transparent and accountable government is a government that implements information and communication technology in building responsiveness, flexibility, and competence to cope with uncertain environmental changes. Intentional information technology is applying management information systems (Dollery et al., 2020) in software applications used to manage financial statements (Zykov and Singh, 2020). The regional financial report management, which typically occurs during the regional autonomy period, is based on the budgeting system's basics and the financial report accountability (Kourtis et al., 2019).

The internal control system is a computer system for computer management (Dollery et al., 2020). IT equipment can change from traditional management to modern management to increase financial statements' efficiency and significance (Jiang 2020). In this regard, Adiputra et al. (2018) and Ode Hasiara (2017) suggested using a management information system that can explain the financial reporting of local government. Financial technology's use and development have influenced many people and many communications (ICT) in everyday life (Afroz, Muhibbullah, and Morshed, 2020). However, the state has yet to develop technological innovation, scientific production, and creative production (Alibekova et al., 2020). Therefore, the importance of management that integrates finance and business through information technology can be implemented through financial management software (Jiang 2020). The use of regional financial information systems is more positive and meaningful for local financial reporting (Aminah, Maisyarah, and AlParok, 2020). Modern society applies information technology to commercial systems (Jiang, 2020). Information technology, economics, and statistical data are available, making the decision-making process more accessible (Ehalaiye, Redmayne, and Laswad, 2020). Thus, the use of information technology applications in the local government's financial reports is better, more transparent, and more accountable.

Some concepts related to government performance on developing transparency and accountability are related with; e-Governance and e-government. E-Governance is a means of delivering government information and services by the government to the 
public in information and communication technology applications (Dilip Singh Sisodia, Shivangi Bhandari, Nerella Keerthana Reddy, 2020). Whereas e-government is an electronic government service, aspects related to transaction transparency and security play a fundamental role in building trust in the services provided (Geneiatakis et al. 2020). The transparency and accountability government still uses e-governance and e-government, but it always focuses on moving quickly and deftly towards a better direction in an intelligent way (Jiang, 2020).

Figure 1. Theoretical Framework Model

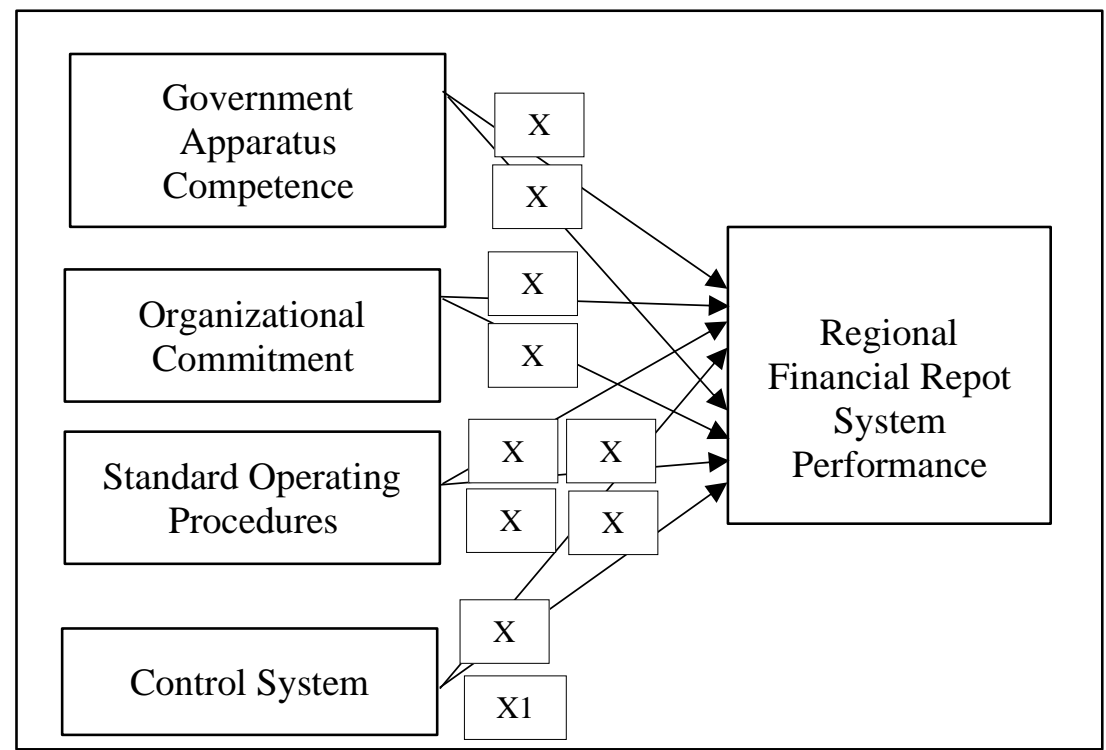

Sources: Adopted from (Lee-Geiller and Lee 2019; Trost 2020; Wahyudin 2017)

The government apparatus competence is defined as a group of structurally different organs working together in the performance (Ehalaiye, Redmayne, and Laswad, 2020). it is the ability to perform a task based on knowledge and expertise. Also, the competence of employees directly impacts the performance of the local government's financial report, which refers to assessing the fairness of the local government financial report carried out by financial auditing agencies.

Hypothesis 1 (H1): Government Apparatus competence significantly influences the Unqualified Opinion (WTP).

The Organizational commitment is the organization's understanding level and it is linked to the organization's objectives. Organizational commitment is an acceptance of the organization's goals and values (Alibekova et al., 2020). In relation, another study also found a similar outcome, which has the research objective of finding the 
internal audit against the organizational performance and finding the effect of the institution's performance.

Hypothesis 2 (H2): Organizational commitment significantly influences the Unqualified Opinion (WTP).

The Standard Operating Procedures (SOPs) are a series of documented and standardized guidelines on the process of implementing the functions of regional government institutions (Jiang 2020).

Hypothesis 3 (H3): SOP has a significant influence on the Unqualified opinion (UO).

While the control system on the financial report ensures that management has accurate, timely, and complete information (Coetsee, 2020), the local government's control system refers to an Unqualified Opinion (UO).

Hypothesis 4 (H4): control system has a positive and significant influence on the Unqualified opinion (UO).

\section{Research Methods and Materials}

This research is included in the quantitative descriptive analysis to get a picture of the object under study (Denzin and Lincoln 2016). The purpose is in the form of data, then analyzed based on the grand theory used as an analysis tool. This research is conducted in South Sulawesi Province because this province becomes a prominent region in eastern Indonesia (Muafi, 2020). The tehniques used are crosstab correlations, interviews, and study documentations. Data were run by Crosstabs to allow using correlation on dependent and independent variables collected from 2015 to 2020, namely a statistical relationship between two variables (Gayo, Nahonyo, and Masao, 2020).

Using a crosstab correlation in predicting the calculated value can be measured from a very appropriate value. According to statistics, this measure is carried out by finding the value of $\mathrm{F}$, the value of $\mathrm{t}$, and the correlation coefficient of determination. The statistical test fuses to indicate whether all the independent variables entered in the model have a joint influence on the dependent variable (Copes and Miller, 2015). Statistical value $F$ is called significant if the f-count is $<0.05$, or if the $f$-count value is $>$ f-table. The next crosstab displayed values or scores in how far the influence of one explanatory/independent variable individually explains the dependent variable's variation. The value of $t$ is declared significant if the calculation results are in the critical area of the hypothesis rejected and declared not significant if the hypothesis is accepted (Tuurnas et al., 2019). Alternatively, by comparing the significance level of $\mathrm{t}$ with $0.05(\alpha=5 \%)$ or comparing $\mathrm{t}$ arithmetic with $\mathrm{t}$-table. If the significance level of $\mathrm{t}$-count is $<0.05$ or if the value of the t-statistic result is greater than the t-table value, 
then the hypothesis is accepted (Wahyudin, 2017). Something more interesting to consider is the crosstab correlation.

In this context, the research area is conducted in the local government by collecting and analyzing the financial report system performance obtained from the local government's official website.

\subsection{Dependent Variable}

The regional financial report system performance of local government i.e., can be divided into four levels. Those performances should become the public disclosure of information by the local government. Besides, the disclosure of financial report details by local government is a key-dependent variable in this analysis. The quality of information accessibility was calculated and used the index as shown by (Tuurnas, Stenvall, Virtanen, Pekkola, and Kurkela (2019), which were updated according to conditions in Indonesia.

Analysis of scoring system:

- 1 = When on the first Google search page, the local government website may be reached by typing the local government's name.

- $+1=$ if only three or fewer clicks are needed on the local government website to access financial and non-financial information.

- $+1=$ if it is possible to access financial and non-financial data in different formats.

- $+1=$ if the website of the local authority provides some previous financial and non-financial records. The highest score is 1 ; the lowest is 0 .

\subsection{Independent Variables}

The availability of the financial report system is a variable to measure the local government's transparency as a result of which future financial report system both of availability and accessibility are expected to be obtained. The independent variable is obtaining from searching the available websites in each regency/city in South Sulawesi Province. The variable Government Apparatus Competence consists of indicators of government structure (X1) and human resources (X2). Organizational commitment standard variables include strategic planning (X3) and public dialogue (X4). Standard operational procedures variables consist of responsive indicators (X5), openness (X6), social media (X7), and document reports (X8). The Control System variable consists of the ICT indicators (X9) and the website to access (X10). By browsing the websites of each Regency / City regarding the availability of the required platform, you get variants X1 to X10. For more details, see the following Table 1:

Table 1. Factors and Indicators

\begin{tabular}{|l|l|l|l|l|l|}
\hline Factors & Indicator & Details & Yes & No & Source \\
\hline & $\begin{array}{l}\text { Government } \\
\text { structure }(\mathrm{X} 1)\end{array}$ & $\begin{array}{l}\text { The existence of a } \\
\text { structure and function }\end{array}$ & 1 & 0 & $\begin{array}{l}\text { Processed } \\
\text { from the }\end{array}$ \\
\hline
\end{tabular}




\begin{tabular}{|c|c|c|c|c|c|}
\hline \multirow{2}{*}{$\begin{array}{l}\text { Government } \\
\text { Apparatus } \\
\text { Competence }\end{array}$} & & $\begin{array}{l}\text { accompanied by an } \\
\text { activity agenda }\end{array}$ & & & \multirow{10}{*}{$\begin{array}{l}\text { website of } \\
\text { each } \\
\text { regency/ci } \\
\text { ty }\end{array}$} \\
\hline & $\begin{array}{l}\text { Human } \\
\text { resources } \\
(\mathrm{X} 2) \\
\end{array}$ & $\begin{array}{l}\text { Human resource } \\
\text { distribution, whether there } \\
\text { is or not }\end{array}$ & 1 & 0 & \\
\hline \multirow[b]{2}{*}{$\begin{array}{l}\text { Organizational } \\
\text { commitment }\end{array}$} & $\begin{array}{l}\text { Strategic } \\
\text { planning (X3) }\end{array}$ & $\begin{array}{l}\text { Vision and Mission, } \\
\text { present or not }\end{array}$ & 1 & 0 & \\
\hline & $\begin{array}{l}\text { Public dialog } \\
\text { (X4) }\end{array}$ & $\begin{array}{l}\text { The comment column is in } \\
\text { the form of criticism and } \\
\text { suggestions, whether or } \\
\text { not there }\end{array}$ & 1 & 0 & \\
\hline \multirow{4}{*}{$\begin{array}{l}\text { Standard } \\
\text { operational } \\
\text { procedures }\end{array}$} & $\begin{array}{l}\text { Responsive } \\
\text { (X5) }\end{array}$ & $\begin{array}{l}\text { The existence of a } \\
\text { performance SOP, } \\
\text { whether there is or not }\end{array}$ & 1 & 0 & \\
\hline & $\begin{array}{l}\text { Openness } \\
\text { (X6) }\end{array}$ & $\begin{array}{l}\text { The existence of a } \\
\text { complaint / response SOP, } \\
\text { whether available or not }\end{array}$ & 1 & 0 & \\
\hline & $\begin{array}{l}\text { Social media } \\
\text { (X7) }\end{array}$ & $\begin{array}{l}\text { The existence of social } \\
\text { media on the official } \\
\text { website, whether there is } \\
\text { or not }\end{array}$ & 1 & 0 & \\
\hline & $\begin{array}{l}\text { Document } \\
\text { report (X8) }\end{array}$ & $\begin{array}{l}\text { Previous year's financial } \\
\text { document reports, whether } \\
\text { available or not }\end{array}$ & 1 & 0 & \\
\hline \multirow[t]{2}{*}{ Control System } & ICT (X9) & $\begin{array}{l}\text { The existence of an e- } \\
\text { system or an official } \\
\text { application, whether there } \\
\text { is or not }\end{array}$ & 1 & 0 & \\
\hline & $\begin{array}{l}\text { Website to } \\
\text { access (X10) }\end{array}$ & $\begin{array}{l}\text { Website access speed, only } \\
\text { three or less clicks }\end{array}$ & 1 & 0 & \\
\hline
\end{tabular}

Source: Authors' data visualized by SPSS.

Hence, the study was conducted using regression analysis with an error rate of 5 percent using an SPSS analysis. Sensitivity analysis was carried out for the dependent variable, i.e. lack of transparency by measuring the level of reporting of local financial information (Tuurnas et al. 2019).

\section{Findings and Discussion}

\subsection{Findings}

The aspects of local government are practically assessed in the drafting of the Regional Government Budget "APBD" and its implementation through the preparation, starting with the planning, approval, implementation, monitoring, and accountability of the parliament (Ode Hasiara 2017). Local government requires the planning procedures to ensure that good public governance is established in a transparency and accountability manner. The analyzed sample data of research (south 
Sulawesi province) is over 24 regencies. The descriptive statistics of the research data is shown in Table 2; it can be seen that the level of transparency and accessibility measured by the local government website at score -1 to 1 , which means that accessing the local government website, financial and non-financial information can be found listed on the indicators.

Table 2. The correlation factors of Transparency and Accountability, 2020

Correlations

\begin{tabular}{|c|c|c|c|c|c|c|c|c|c|c|c|}
\hline \multicolumn{2}{|c|}{ Control Variables } & 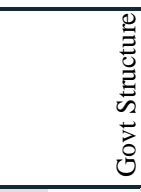 & 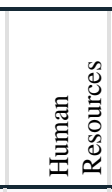 & 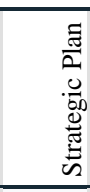 & $\frac{\infty}{3}$ & 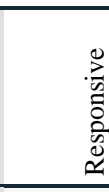 & 峁 & 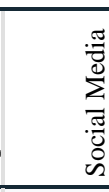 & 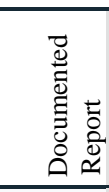 & 包 & 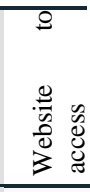 \\
\hline \multirow{10}{*}{$\begin{array}{l}\text { TRANSPAR } \\
\text { ENCY\&ACC } \\
\text { OUNTABILI } \\
\text { TY }\end{array}$} & Govt Structure & 1.000 & .021 & .028 & -.123 & -.259 & -.335 & -.211 & .267 & -.036 & -.037 \\
\hline & Human Resources & .021 & 1.000 & -.027 & .166 & $-.409^{*}$ & -.295 & .249 & -.006 & .065 & -.233 \\
\hline & Strategic Plan & .028 & -.027 & 1.000 & -.333 & .275 & -.183 & -.029 & .041 & -.336 & -.127 \\
\hline & Public Dialog & -.123 & .166 & -.333 & 1.000 & -.092 & -.254 & -.263 & .184 & .277 & $.505^{* *}$ \\
\hline & Responsive & -.259 & $-.409^{*}$ & .275 & -.092 & 1.000 & .290 & $-.547^{* *}$ & 186 & -.089 & $-.419^{*}$ \\
\hline & Openness & -.335 & -.295 & -.183 & -.254 & .290 & 1.000 & -.222 & 186 & -.089 & $-.419^{*}$ \\
\hline & Social Media & -.211 & 249 & -.029 & -.263 & $-.547^{* *}$ & -.222 & 1.000 & -.119 & -.192 & .053 \\
\hline & $\begin{array}{l}\text { Documented } \\
\text { Report }\end{array}$ & . 267 & -.006 & .041 & .184 & .186 & -.119 & $-.602^{* *}$ & 1.000 & -.032 & $-{ }^{-} .518^{* *}$ \\
\hline & ICT & t. -.036 & .065 & -.336 & .277 & -.089 & -.192 & -.241 & -.032 & 1.000 & -.336 \\
\hline & Website to access & 已 -.037 & -.233 & -.127 & $-.505^{* *}$ & $-.419^{*}$ & .053 & $.625^{* *}$ & $-.518^{* *}$ & -.336 & 1.000 \\
\hline
\end{tabular}

Source: Authors' data visualized by SPSS.

Table 2 shows the results of correlation tests based on the official website information. It can be concluded that the adoption of the ICT base is still superficial, as almost all local governments adopt a formal reporting system.

The most variable indicators (10) are those related to public dialogue and reaction speed. The third indicator is openness. These three indicators were dominant in determining the opinion on the results of the local administration's financial audits. The local government has used other means of information technology to hold public dialogues on regional regulatory policies, including the annual budget. The receptivity indicator refers to the quick response to any suggestions and criticisms, and openness refers to the knowledge and understanding of financial policies.

\subsection{Government Apparatus Competence and Organizational Commitment}

To improve the public service, the governments may have to address the following key areas of websites to develop further transparency (Adiputra, Utama, and Rossieta, 2018). Transparency appears primarily to be driven by local governments' dependent variables. The profile of government apparatus (bureaucracies in local government) has a direct bearing on transparency. Depending on the actual competence and organizational commitment - for example, competence or strong commitment, 
government apparatus may be especially relevant for the local government's overall attitude towards transparency.

The level of transparency assessed by usage accessibility level for local government percentage is $27.5 \%$, which means that visitors may have to find three clicks or less to view financial and non-financial information on Google's first search page when people visit a local government website.

Table 3. Government Apparatus Competence and Organizational Commitment, 2020 Correlations

\begin{tabular}{|c|c|c|c|c|c|c|c|c|c|c|c|c|}
\hline \multicolumn{3}{|c|}{ Control Variables } & 吾 & 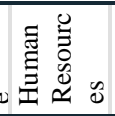 & 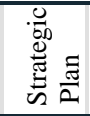 & 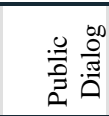 & 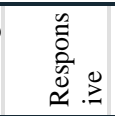 & 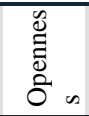 & 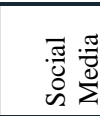 & 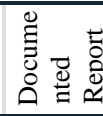 & 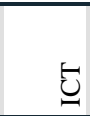 & $\begin{array}{l}0 \\
0 \\
0 \\
0 \\
0 \\
0 \\
0 \\
0 \\
0\end{array}$ \\
\hline \multirow{4}{*}{$\begin{array}{l}\text { Government } \\
\text { Apparatus } \\
\text { Competence } \\
\text { and } \\
\text { Organizational } \\
\text { Commitment }\end{array}$} & Govt Structure & \multirow{4}{*}{ 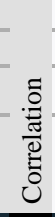 } & 1.000 & .021 & .028 & -.123 & $\mid-.259$ & -.335 & -.211 & .267 & $\begin{array}{l}.036 \\
\end{array}$ & -.037 \\
\hline & Human Resources & & .021 & 1.000 & -.027 & .166 & $-.409^{*}$ & -.295 & .249 & -.006 & .065 & -.233 \\
\hline & Strategic Plan & & .028 & -.027 & 1.000 & -.333 & .275 & -.183 & -.029 & .041 & -.336 & -.127 \\
\hline & Public Dialog & & -.123 & .166 & -.333 & 1.000 & -.092 & -.254 & -.263 & .184 & .277 & $.505^{*}$ \\
\hline Correlation $\mathrm{i}$ & significant at 0.05 & & & & & & & & & & & \\
\hline
\end{tabular}

Source: Authors' data visualized by SPSS

In Table 3, it can be seen that the dominant variables and the indicator of the competence of government apparatuses and organizational commitment have an average score of $>0-1$. At the same time, the lowest score indicator has an average score of $<0$.

Two variables are measured, namely the competence of the government apparatus and organizational commitment. SPSS analysis is used to answer the research hypothesis. The government apparatus's competence is influenced by two indicators, namely X1 and $\mathrm{X} 2$, where three regencies are not significant, and two regencies are significant. The government structure has a significant effect, as local governments have established that their government organizational structure refers to regional regulations, in which they are under the Regional Legislature (DPRD). Thus, the realization of organizational structures has a strong authority and legitimacy in its implementation. The X2 indicator is low due to the distribution or placement of human resources. The decision to place employees in a position is based less on basic factors: competence and ability. This study's results are consistent with the study (Tavare and da Cruz, 2017) on human resources.

The variable of government commitment thereby includes there indicators; $\mathrm{s}$ organizational commitment including indicators $\mathrm{X} 3$ on strategic planning and $\mathrm{X} 4$ public dialogue; there are six regencies that do not publish their documents websitebased system related to strategic planning and documents, and five regencies that have applications or dialogue platforms in providing accessibility of information. Documented strategic planning by the local governments is still considered the 
material belonging to the government, so they are not well-published, even though the local government already has websites and applications platform for public dialogues. The study showed the implications of local government efforts to produce local government financial reports with existing legislation or standard operating procedures.

\subsection{Standard Operating Procedures}

In this context, the reporting of regional financial information in its development should be related to its assessment in Local Government Financial Statements/Laporan Keuangan Pemerintah Daerah (LKPD) as a form of accountability for the implementation of the Regional Government Budget / Anggaran Pendapatan and Belanja Daerah (APBD) in line with government financial reporting as established by the Government (Pamungkas, Ibtida, and Avrian, 2018).

Factors affecting transparency and accountability of local government report system are the variable of standard operating procedures explained in Table 4.

Table 4. Standard Operating Procedures, 2020

Correlations

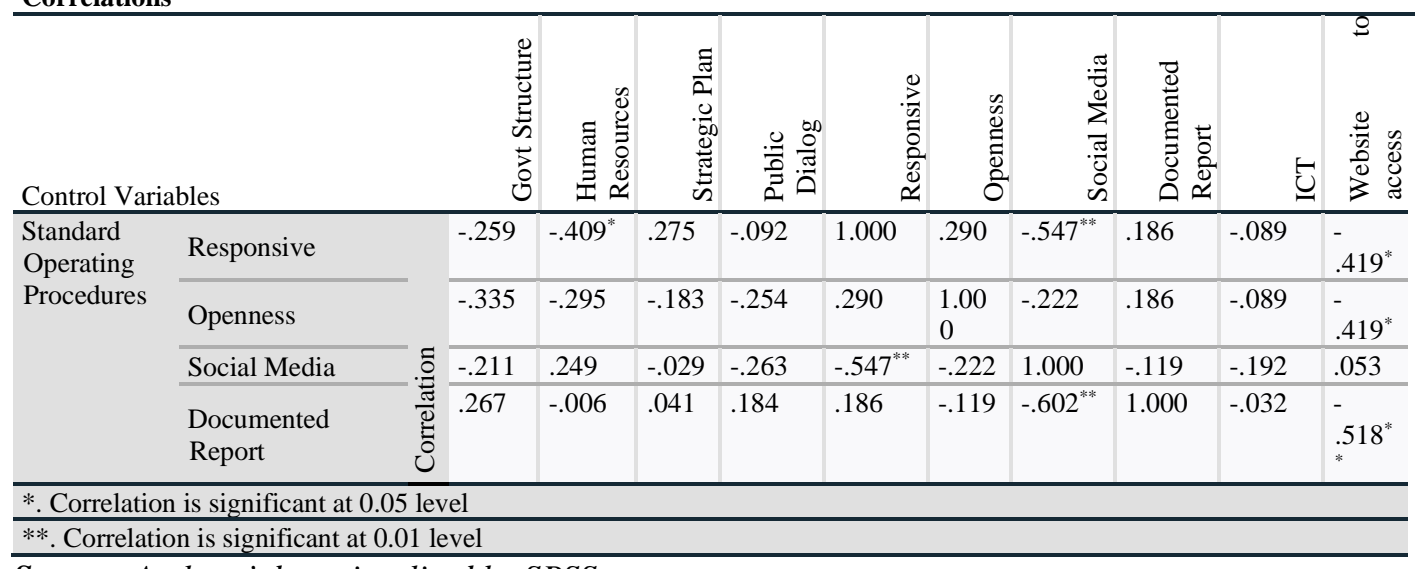

Source: Authors' data visualized by SPSS.

As shown in Table 4, the variable of standard operating procedures (SOP) X5, X6, $\mathrm{X} 7$, and $\mathrm{X} 8$, are responsiveness, openness, social media, documented reports. There are seven regencies/cities that are affected by unresponsiveness; there are nine regencies related to openness and six regencies with documented reports, and seven regencies with a social media platform. It indicates that Standard Operational Procedure has not become an optimal means to public services because 24 regencies follow old public management procedures. Thus, openness, social media, and documented reports as an SOP must be implemented. 
SOP operates according to the reporting system role and competence of the state civilian apparatus dealing with reporting. The factor that influences the transparency and accountability of reports on the use of local government budgets is the factor that affects the quality of local government financial reports and is an indicator of understanding government accounting standards (SAP). This study's results are in line with the study (Hilmi, 2018) and indicate that standard audit operating procedures affect the financial report through the internet-based system.

\subsection{Control System}

Financial information on websites may also be used as an alternative to reporting methods to establish responsible and transparent local government responsibilities (Ode Hasiara, 2017). The local government financial report's objectives for 2020 should receive an unqualified opinion from $60 \%$ of the BPK 's review results. The Audit Board (BPK) as professional accounting of examination standard. In practice, it is not easy to get that opinion. It is due to the less performance of the existing human resources in the government.

Table 5. Control System, 2020

\section{Correlations}

\begin{tabular}{|c|c|c|c|c|c|c|c|c|c|c|c|c|}
\hline \multicolumn{3}{|c|}{ Control Variables } & 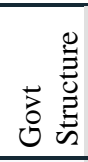 & 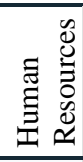 & 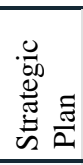 & $\frac{0}{\stackrel{0}{0}} \frac{0}{0}$ & 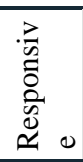 & $\begin{array}{l}\tilde{d} \\
\stackrel{\Xi}{\Xi} \\
\tilde{\Xi}\end{array}$ & 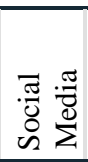 & 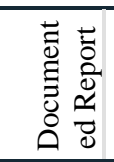 & 气 & 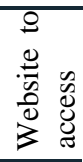 \\
\hline \multirow[t]{2}{*}{$\begin{array}{l}\text { Control } \\
\text { System }\end{array}$} & ICT & \multirow{2}{*}{ 造 } & -.036 & .065 & -.336 & .277 & $\begin{array}{l}- \\
.089\end{array}$ & -192 & - & -.032 & $\begin{array}{l}1.00 \\
0 \\
\end{array}$ & -.336 \\
\hline & $\begin{array}{l}\text { Website } \\
\text { to access }\end{array}$ & & -.037 &.- & 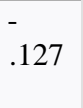 & $.505^{* *}$ & $\begin{array}{l}- \\
* \\
*\end{array}$ & .053 & .625 & $.518^{* *}$ & -.336 & $\begin{array}{l}1.00 \\
0\end{array}$ \\
\hline \multicolumn{13}{|c|}{ *. Correlation is significant at 0.05 level } \\
\hline \multicolumn{13}{|c|}{ **. Correlation is significant at 0.01 level } \\
\hline
\end{tabular}

Source: Authors' data visualized by SPSS.

There are seven regencies with insignificant ICT, and seven of 24 districts are significant about the 'website to access. Hence, ICT and website access have not been used as a means of the control system. Local governments pay less attention to the benefits of ICT and websites to access regional financial reports. This factor is caused by human resources' capability and the lack of supervision and awareness of local government officials.

The influences of independent variables on the dependent variable are also called the determination (Lee-Geiller and Lee, 2019). This implies that the impact of the independent variable (regional financial management information system) on the dependent variable (Transparency and accountability Report on the use of Local Government budget) are not examined in this study. As a result, it can be seen that 
with a significant level of probability, the correlation coefficient can be used to predict the variable quality of the local government financial report system.

Based on the correlation coefficient, the constant value is $0,>0$. Likewise, the result finds out whether the management information system significantly affects the transparency and accountability of local government budget use reports. So, it can be concluded that the financial report system has several significant factors and indicators that affect the transparency and accountability of local government budgetuse reports.

The audit reported that unqualified opinion is needed by all parties, clients, users, and financial information auditors. An unqualified opinion means free from doubt, dishonesty, and information (Ode Hasiara, 2017). This opinion is limited to the amount of Rupiah and disclosures stated in the financial statements and the accuracy of the classification of the information obtained. Based on the analysis, four factors (see Table.2-5) affect the financial reporting system to improve the accountability and transparency of local government (as shown in table 1). However, we found that those categorized as UO were mostly significant about the indicators and variables, while less significant QO and AO/DoO about less information availability and accessibility.

Table 6. The report results of the quality of financial accountability in South Sulawesi, 2020

\begin{tabular}{llllll}
\hline Regencies/City & $\mathbf{2 0 1 9}$ & $\mathbf{2 0 1 8}$ & $\mathbf{2 0 1 7}$ & $\mathbf{2 0 1 6}$ & $\mathbf{2 0 1 5}$ \\
\hline Sinjai & UO & UO & UO & UO & QO \\
\hline Enrekang & UO & UO & UO & UO & DoO \\
\hline Bulukumba & UO & UO & UO & UO & UO \\
\hline Sidrap & UO & UO & UO & UO & UO \\
\hline Gowa & UO & UO & UO & UO & UO \\
\hline Takalar & UO & QO & QO & QO & QO \\
\hline Bantaeng & UO & UO & UO & UO & UO \\
\hline Wajo & UO & UO & UO & UO & UO \\
\hline Luwu & UO & UO & UO & UO & UO \\
\hline Pangkep & UO & UO & UO & UO & UO \\
\hline Selayar & UO & UO & UO & UO & UO \\
\hline Maros & UO & UO & UO & UO & UO \\
\hline Barru & UO & UO & UO & UO & AO \\
\hline Pinrang & UO & UO & UO & UO & UO \\
\hline Tanah Toraja & UO & QO & QO & QO & AO \\
\hline Toraja Utara & UO & UO & UO & UO & UO \\
\hline Bone & UO & UO & UO & UO & UO \\
\hline Soppeng & UO & UO & UO & UO & UO \\
\hline Luwu Utara & UO & UO & UO & UO & UO \\
\hline Luwu Timur & UO & UO & UO & UO & UO \\
\hline Palopo & UO & UO & UO & UO & UO \\
\hline Pare Pare & UO & QO & UO & UO & UO \\
\hline Makassar & UO & UO & UO & UO & UO \\
\hline & & & & & \\
\hline & & & & & UO \\
\hline
\end{tabular}


Source: Authors' data visualized by SPSS.

Validity and reliability were used for evaluating the government apparatus competence, organizational commitment, SOP, and control system, from 24 regencies of south Sulawesi.

\section{Discussion}

Transparency and accessibility have a significant effect on local governments as openness and accountability would address government problems and the key to the implementation of good governance (Lee-Geiller and Lee, 2019; Tavares and da Cruz, 2017; Medina, 2012). The more transparent and accountable the local government's implementation is, the more likely it is to get an unqualified opinion on the financial report system (Agustin and Arza 2020; Aminah, Maisyarah, and AlParok, 2020).

The results of this study are in line with Cleveland and Cleveland (2020), Ehalaiye, Redmayne, and Laswad (2020), Helms and Nixon (2010), and Muafi (2020) who stated that government apparatus and organization competence through improving human resources have an important role in underpinning the transparency practices of local governments in Indonesia, in publishing financial report through the website.

The financial report system shows the major or dominant factors and indicators that support transparency and accountability, which are found in the government competence apparatuses and organizational commitment. On the other hand, two factors are less significant: the standard operating procedures and control system. In terms of indicators, the most significant that supports transparency and accountability, namely government structure, and the weakness indicator is ICT because some do not explicitly use the accessibility of the website-based system.

The ease of "Website to access" still dominates the low answers, following the "public service portal," even though information technology infrastructure is already available. Flexibility should be quickly implemented in these conditions by learning new procedures (Moon, 2020), including fast learning from mistakes (Pfeffermann, 2020). Not easily accessible means the application of management information systems is new for managers of local government financial reports.

These conditions have an impact on the transparency and accountability of reports on the use of local budgets. This indicates that information technology can be implemented through financial management software (Jiang, 2020). However, the "ICT" and "documented report" of the indicator still need improvement. Financial and statistical data still need to be improved for decision-making (Ehalaiye, Redmayne, and Laswad, 2020). The aim is to make the regional government's financial reports better, more transparent, and more accountable. 
The factors that affect the accountability and transparency of the financial reporting system, according to Table 2, are the level of understanding of major factors and indicators - the role of SOP, strategic planning, and social media related to human resource flexibility. Learn new procedures quickly (Moon, 2020), adapt to standardization (Idowu et al., 2020), and information technology (Cleveland and Cleveland 2020; Helms and Nixon 2010). Human resources for information technology and the innovation process are the main keys to influencing the local governor's quality of the financial reporting system. Knowledge can improve organizational innovation (Muafi, 2020). By raising awareness of information, communication technology can improve innovation in the quality of the financial report.

Correlation coefficient tests found that standard operating procedures and the control system significantly affect the transparency and accountability of reports on the use of local government budgets (y). So, we need not only receptivity and openness but also competence in human resources. It takes human resources and skills (Kalkan et al., 2020) to motivate employees, so they also want to change and innovate. Human resources motivate subordinates to cultivate knowledge (Pereira et al., 2020) to respond to external environment changes. Even if the management information system based on application technology is included in influenced factors, if human resources do not meet with ICT in implementing the change of management process, the local government budget reporting system's transparency and accountability would be affected.

Therefore, the competence of the government apparatus, organizational commitment, SOP and control system, which are classified according to government structure, human resources, strategic plan, public dialogue, receptive, openness, social media, documented report, ICT, a website for access in conjunction with an adverse opinion $(\mathrm{AO})$, waiver of opinion (DoO), qualified opinion (QO) and unqualified opinion (UO).

\section{Conclusions}

The paper discusses the correlations of significant factors that influence the financial reporting system in local government. Based on the correlation coefficient test results, based on which it was found that standard operating procedures and the control system significantly affect the transparency and accountability of reports on the use of local government budgets.

Research has shown that apparatuses of governmental competence and organizational commitment as the main factors of significance, standard operating procedures, and control systems are less significant; this would be a recommendation to support local government in achieving transparency and accountability and obtaining an unqualified opinion. On the other hand, in terms of indicators, the most significant that supports transparency and accountability, namely government structure, and the indicator of weakness is ICT. 
Correlation testing is based on official website information, and it can be concluded that the ICT base's adoption is still superficial, as almost all local authorities adopt official reporting systems. Based on local government data, some do not explicitly indicate the accessibility of the financial reporting system. The unqualified opinion of the audit report affects the financial reporting system to improve the local government's accountability and transparency, particularly 24 regents, South Sulawesi Province, Indonesia. The financial reporting system needs to implement good governance to respond to uncertain environmental changes, particularly related to the opinion on the financial statements based on the assessment of the Supreme Audit Committee.

Finally, the local government should consider maintaining governmental competence and organizational commitment as the main significance and improving the standard operating procedures and control system, which are less significant.

\section{References:}

Adiputra, I Made Pradana, Sidharta Utama, Hilda Rossieta. 2018. Transparency of Local Government in Indonesia. Asian Journal of Accounting Research 3(1), 123-138.

Afroz, Rafia, Md. Muhibbullah, Mohammad Niaz Morshed. 2020. Impact of Information and Communication Technology on Economic Growth and Population Health in Malaysia. The Journal of Asian Finance, Economics and Business 7(4), 155-162.

Agustin, Henri, Fefri Indra Arza. 2020. Potrait of Accountability and Transparency in Local Budget Management by the Regional Government in West Sumatera Province, Indonesia: An Anomaly in Digital Era. In Proceedings of the 4th Padang International Conference on Education, Economics, Business and Accounting (PICEEBA-2 2019), Paris, France, Atlantis Press, 154-166.

Alibekova, Gulnaz, Tunc Medeni, Aksana Panzabekova, Dinara Mussayeva. 2020. Digital Transformation Enablers and Barriers in the Economy of Kazakhstan. The Journal of Asian Finance, Economics and Business 7(7), 565-575.

Alkilani, Saleh Zaid, Wan Nordin, Wan Hussin, Basariah Salim. 2020. The Relationship between the Characteristics of a Risk Management Committee and the Issuance of a Modified Audit Opinion in the Jordanian Context. Asian Journal of Accounting and Finance 2(2), 52-73.

Aminah, Siti, Nyimas Dian Maisyarah, AlParok. 2020. Regional Financial Information Systems Effect on Sarolangun Local Government Financial Transparency and Accountability of Financial Report. In Proceedings of the International Conference on Public Administration, Policy and Governance (ICPAPG 2019), Paris, France, Atlantis Press, 35-42.

Bidin, M., Azhar, I., Engku, I., Engku, A., Syed, S., Syed, I.Z. 2004. Qualified Audit Reports of Local Authorities in the Northern States of Malaysia. Malaysian Management Journal 8(2), 77-86.

Bourjade, M., Hélène, C., Sandra, M., Michèle, G. 2020. Is Conceptual Diversity an Advantage for Scientific Inquiry? A Case Study on the Concept of 'Gesture' in Comparative Psychology. Integrative Psychological and Behavioral Science.

Çağlar, K., Macide, B., Kenan, A. 2020. The Role of 4PL Provider as a Mediation and 
Supply Chain Agility. Modern Supply Chain Research and Applications, 2(2), 99-111.

Cleveland, M., Simon, C. 2020. Culturally Agile Leadership. International Journal of Public and Private Perspectives on Healthcare, Culture, and the Environment, 4(1), 1-9.

Coetsee, D. 2020. The Underlying Concepts of the Definition of a Liability in Financial Reporting: A Doctrinal Research Perspective. South African Journal of Accounting Research, 1-22.

Copes, H., Miller, M.J. 2015. The Routledge Handbook of Qualitative Criminology. The Routledge Handbook of Qualitative Criminology.

Denzin, N.K., Yvonna, S. 2016. Introduction: The Discipline and Practice of Qualitative Research. In Strategies of Qualitative Inquiry, 3rd Ed., Thousand Oaks, CA, US, Sage Publications, Inc, 1-43.

Dilip, S.S., Shivangi, B., Nerella, K.R., Abinash, P. 2020. Performance and its Applications of Integrated Systems Management in Software Engineering Performance Management of Integrated Systems and Its Applications in Software Engineering. Eds. Millie Pant, Tarun, K. Sharma, Sebastián Basterrech, and Chitresh Banerjee. Singapore, Springer.

Dittrich, Y., Jan, P.H., Kristian, H.M. 2005. How to Make Government Agile to Cope with Organizational Change. In Business Agility and Information Technology Diffusion. Boston, Kluwer Academic Publishers, 333-351.

Dollery, B., Harry, K., Melville, M., Anwar, S. 2020. Local Public, Fiscal and Financial Governance Local Public, Fiscal and Financial Governance. Cham, Springer International Publishing.

Doz, Y., Mikko, K., Petrim V. 2018. Strategically Agile Government. In Global Encyclopedia of Public Administration, Public Policy, and Governance, Cham, Springer International Publishing, 1-12.

Ehalaiye, D., Nives, B.R., Fawzi, Laswad. 2020. Does Accounting Information Contribute to a Better Understanding of Public Assets Management? The Case of Local Government Infrastructural Assets. Public Money \& Management, 1-11.

Ezcan, V., Jack, S.G., Mohammed, A. 2020. Redefining ICT Embeddedness in the Construction Industry: Maximizing Technology Diffusion Capabilities to Support Agility. Building Research \& Information, 1-23.

Gayo, L., Cuthbert, L.N., Catherine, A.M. 2020. Socioeconomic Factors Influencing Local Community Perceptions Towards Lion Conservation: A Case of the Selous Game Reserve, Tanzania. Journal of Asian and African Studies, 0021909620929382.

Geneiatakis, D. et al. 2020. Blockchain Performance Analysis for Supporting Cross-Border E-Government Services. IEEE Transactions on Engineering Management, 1-13.

Gong, Z., Jun, Y., Xiaojie, S. 2020. Towards a Comprehensive Understanding of Digital Transformation in Government: Analysis of Flexibility and Enterprise Architecture. Government Information Quarterly, 37(3), 101487.

Hardiningshi, P., Udin, U., Greg, N.M., Ceacilia, S. 2020. Does Competency, Commitment, and Internal Control Influence Accountability? The Journal of Asian Finance, Economics and Business 7(4), 223-233.

Hassan, I., Nour, A. 2020. The Impact of Organizational Intelligence on Organizational Agility: An Empirical Study in Syrian Private Banks the Impact of Organizational Intelligence on Organizational Agility: An Empirical Study in SYRIAN Private Banks. Human Resource Management Academic Research Society, 10(2), 465-483.

Helms, M.M., Judy, N. 2010. Exploring SWOT Analysis -Where Are We Now? Journal of Strategy and Management, 3(3), 215-251.

Hilmi, M.F. 2018. Responsible Innovation in the Financial Sector: An Islamic Perspective. Journal of Responsible Innovation, 5(2), 247-252. 
Idowu, S.O., Henk, J.V., Ivana, M., Donggeun, C. 2020. Sustainable Development. Eds. Samuel O. Idowu, Henk J. de Vries, Ivana Mijatovic, and Donggeun Choi. Cham, Springer International Publishing.

Jiang, X. 2020. Analysis of Information Technology Application in the Financial Management of Enterprises. Journal of Physics: Conference Series 1533, 022047.

Kalkan, Ü. et al. 2020. The Relationship Between School Administrators' Leadership Styles, School Culture, and Organizational Image. SAGE Open, 10(1), 215824402090208.

Khan, Z., Vivek, S., Amir, S. 2020. Global Post-Merger Agility, Transactive Memory Systems and Human Resource Management Practices. Human Resource Management Review, 30(1), 100697.

Kourtis, E., Kourtis, G., Curtis, P. 2019. An Integrated Financial Ratio Analysis as a Navigation Compass through the Fraudulent Reporting Conundrum: A Case Study. International Journal of Finance, Insurance and Risk Management, 9(1-2), 3-20. DOI: $10.35808 / \mathrm{ijfirm} / 187$.

Lee-Geiller, S., Taejun, D.L. 2019. Using Government Websites to Enhance Democratic EGovernance: A Conceptual Model for Evaluation. Government Information Quarterly 36(2), 208-225.

Moon, M.J. 2020. Fighting COVID-19 with Agility, Transparency, and Participation: Wicked Policy Problems and New Governance Challenges. Public Administration Review, 80(4), 651-656.

Muafi, M. 2020. A Nexus among Strategic Orientation, Social Network, Knowledge Sharing, Organizational Innovation, and MSMEs Performance. The Journal of Asian Finance, Economics and Business, 7(6), 327-338.

Nurmandi, A., Eko, P.P. 2015. International Review of Public Administration Making the Strategic Plan Work in Local Government: A Case Study of Strategic Plan Implementation in Yogyakarta Special Province ( YSP ). International Review of Public Administration, 16(2), 143-164.

Nuryati, T., Bayu, P., Puja, R. 2020. Improving the Quality of Financial Reports by Implementing SIMAK-BMN in KPU-RI. In Proceedings of the Annual International Conference on Accounting Research (AICAR 2019), Paris, France, Atlantis Press, 157 161.

Ode Hasiara, L. 2017. Analysis of Giving Opinion of the Audit Board of the Republic of Indonesia (BPK) on Unqualified Opinion (WTP). Journal of Finance and Accounting, 5(6), 206.

Pamungkas, B., Reisya, I., Cendy, A. 2018. Factors Influencing Audit Opinion of the Indonesian Municipal Governments' Financial Statements. Cogent Business and Management, 5(1), 1-18.

Paul, M., Lalatendu, K.J., Kalpana, S. 2020. Workplace Spirituality and Workforce Agility: A Psychological Exploration Among Teaching Professionals. Journal of Religion and Health, 59(1), 135-153.

Pereira, V. et al. 2020. Investigating Investments in Agility Strategies in Overcoming the Global Financial Crisis - The Case of Indian IT/BPO Offshoring Firms. Journal of International Management, 100738.

Pfeffermann, N. 2020. New Leadership in Strategy and Communication New Leadership in Strategy and Communication. Ed. Nicole Pfeffermann. Cham, Springer International Publishing.

Purnomo, E.P. et al. 2019. Land Ownership Transformation before and after Forest Fires in Indonesian Palm Oil Plantation Areas. Journal of Land Use Science, 1-15.

Tavares, A.F., Nuno, F.C. 2017. Explaining the Transparency of Local Government Websites 
What Factors Affect Financial Transparency Reports? A Study of Regional Government Financial Reports in South Sulawesi Province, Indonesia

544

through a Political Market Framework. Government Information Quarterly, 0-1.

Trost, A. 2020. Human Resources Strategies Human Resources Strategies. Cham, Springer International Publishing.

Tuurnas, S., et al. 2019. Towards Collaborative Development Culture in Local Government Organisations. International Journal of Public Sector Management.

Wahyudin, A. 2017. Factors Influencing the Quality of Financial Reporting on Local Government of Purbalingga. Accounting Analysis Journal, 6(1), 27-38.

Zykov, S.V., Amitoj, S. 2020. Agile Enterprise Engineering: Smart Application of Human Factors Agile Enterprise Engineering: Smart Application of Human Factors. Cham, Springer International Publishing. 